Division, and upon approval of such memorandum by the Attorney General, the matter goes to the Trial Section of the Division. The considerations bearing upon the decision to take court action are discussed in the succeeding article.

\title{
II. THE SELECTION OF CASES FOR MAJOR INVESTIGATIONS
}

\author{
FowLer HAMILTON*
}

An attempt is made by the Antitrust Division of the Department of Justice to conduct at least a preliminary investigation of all complaints which give promise of being meritorious. Frequently the complainant is a business man unfamiliar with the requirements of the federal antitrust laws, and his complaint is usually limited to a very general description of practices which appear to him to violate the antitrust laws. In such a case the complainant is requested to supply additional information. Characteristically this relates to such matters as a more definite description of the practices alleged to be unlawful, facts showing that interstate commerce is restrained by these practices, the names and addresses of the persons or corporations involved and information about other persons who might have felt the impact of the restraints.

If the additional information supplied supports the original complaint, a preliminary investigation of the situation is undertaken by agents of the Federal Bureau of Investigation who conduct a thorough investigation based on information supplied by the complainant. Following this inquiry, the Economic Section of the Antitrust Division then prepares a study of the industry involved. It is the purpose of the economic analysis not only to shed light upon the validity of the complaint but to present a general picture of the industry so that the practices involved may be viewed in perspective and their economic and social consequences observed.

The economic survey may reveal that practices on their face questionable are in fact shaped by the play of competitive forces. A recent complaint charged that a rigid system of uniform prices prevailing among a large number of producers of a given commodity was the result of concerted action. Preliminary investigation disclosed that in fact a highly rigid price pattern existed. Deviations from this pattern were practically unknown and identical alterations in the price structure occurred simultaneously among all sellers. It seemed very improbable that such an ordered price policy could be imposed upon a field replete with variables except through the discipline of agreement.

An economic study of the situation disclosed that the prices in question were in fact established by competition. The large group of small producers sold to a few

- B.A., 1931, University of Missouri; B.A. in Jurisprudence, 1933; B.C.L., 1934, Oxford University. Member of the Missouri Bar. Special Assistant to the Attorney General, and Assistant Chief of the Complaints Section, Antitrust Division, United States Department of Justice. Contributor to legal periodicals. 
large buyers. These buyers were retailers who had established certain categories of price at which they disposed of their articles. Prices paid to producers were directly derived from the retail prices. Thus the rigidity created by market practice in the retail end of the industry determined the pattern which the preliminary investigation had shown to exist in the prices paid producers. Consequently no action was taken upon the complaint because the prices in question, although rigid and uniform, were determined by bargaining in a competitive market.

Where the economic study indicates that further action is required, it also frequently discloses that the complaint does not exhaust the questionable practices in the industry. A complainant ordinarily does not feel the full impact of combination in restraint of trade, and his protest may be merely a clue to a larger violation.

The importance of the economic analysis is not limited to the preliminary investigation. The facts about profits, production, prices and the working of the industry which it produces constitute the basis for a decision regarding further action. In addition, such a study yields information from which a plan for a comprehensive study can be made.

Limitations of personnel alone make it impossible to continue beyond the preliminary stage every inquiry which discloses practices which are questionable under the federal antitrust laws. In this connection, it should be noted that the purpose both of the preliminary and of the general investigation is merely to determine whether enforcement by way of legal action is necessary. No decision of this question is made until investigation is completed. When the investigation has proceeded to a point which makes it clear that no unlawful conduct is involved, it is terminated. Frequently, a general investigation is necessary before final decision regarding enforcement can be reached.

Since the general investigation cannot be conducted in every case where one is warranted, efficient enforcement requires a careful process of selection. Among the factors involved in determining when a major investigation should be undertaken are: personnel available, the extent and nature of the information which the preliminary investigation has disclosed, the economic advantage that will be secured if it is finally determined that the complaint is well founded and legal action necessary, and the enforcement effect of such action.

It is difficult to overemphasize the restrictions that limitations of personnel impose upon the selection of cases for major investigation. Generally the number of such investigations undertaken in the course of a year depends upon the amount of the annual appropriation, ${ }^{1}$ much of which must be expended for the enforcement of

\footnotetext{
${ }^{2}$ Regular and deficiency appropriations for enforcement of federal antitrust laws and other statutes under the jurisdiction of the Antitrust Division of the Department of Justice, from the fiscal year $x 903$ to I940, inclusive, have been as follows:

\begin{tabular}{|c|c|c|c|c|c|c|c|}
\hline $\begin{array}{c}\text { Fiscal Year } \\
\text { Ending } \\
\text { June } 30\end{array}$ & Appropriation & $\begin{array}{l}\text { Ending } \\
\text { Fiscal Year } \\
\text { June } 30\end{array}$ & Appropriation & $\begin{array}{c}\text { Fiscal Year } \\
\text { Ending } \\
\text { lune } 30\end{array}$ & Appropriation & $\begin{array}{c}\text { Fiscal Year } \\
\text { Ending } \\
\text { lune } 30\end{array}$ & Appropriation \\
\hline $\begin{array}{l}1903 \ldots . . \\
1904 \ldots .\end{array}$ & $\begin{array}{r}\$ 500,000.00 \\
\text { bal. available }\end{array}$ & $\begin{array}{l}1905 \ldots \ldots \\
1906 \ldots . .\end{array}$ & bal. available & $\begin{array}{l}1907 \ldots \ldots \\
1908 \ldots \ldots\end{array}$ & $\begin{array}{r}\text { bal. available } \\
250,000.00\end{array}$ & $\begin{array}{l}1909 . . . \\
1910 . . .\end{array}$ & $\begin{array}{l}250,000.00 \\
100,000.00\end{array}$ \\
\hline
\end{tabular}
}


laws other than the Federal Antitrust Acts. The Antitrust Division is required to handle legal proceedings in connection with thirty statutes besides the Sherman Act and the Clayton Act. ${ }^{2}$

Since the budget for the Antitrust Division of the Department of Justice must be formulated from six to nine months before the fiscal year to which it is applicable, it is difficult to anticipate future requirements. Experience in the enforcement of the antitrust laws in recent years has demonstrated that the more actively those laws are enforced the greater demand there is for enforcement. Since active enforcement quickly absorbs available personnel, the Antitrust Division is faced with a continuously expanding demand by the public for the consideration of complaints and the initiation of investigations which limitations of personnel make it impossible to meet in full. It is also well-nigh impossible to provide in the budget for sufficient personnel to handle emergencies. Thus, when a rapid general price advance occurred following the commencement of war in September, the Department received as many as 250 complaints a day requesting immediate action. With available personnel actively engaged in other matters it was obviously impossible to give adequate consideration to these complaints.

Though in recent years this limitation on personnel has been mitigated somewhat, ${ }^{3}$ it remains the most significant factor in the selection of matters for major investigation. It is usually the case that all but a few of the lawyers and economic experts available for the supervising of general investigations are engaged in major matters. The nature of an antitrust investigation is such that personnel cannot be taken off one matter and placed on another readily, since a major investigation usually takes from six months to a year.

Once a staff is organized to handle a major investigation, it would be wasteful and inefficient to divert members of the group to other work. Consequently, the selection of major investigation is shaped not so much by the amount of personnel

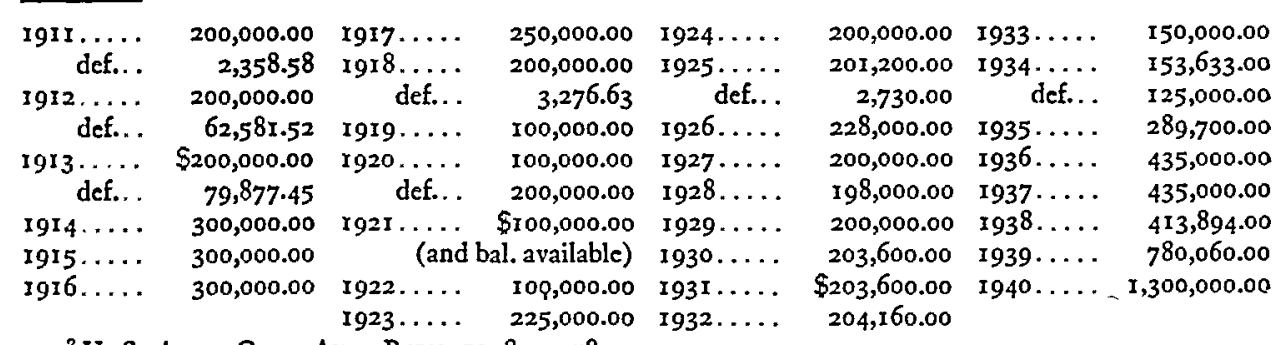

2 U. S. ATtr. Gen., ANn. Rept. 1938, p. 58.

"The number of lawyers employed by the Antitrust Division from the fiscal year 1903 to June 30 , 1939, is set out below:

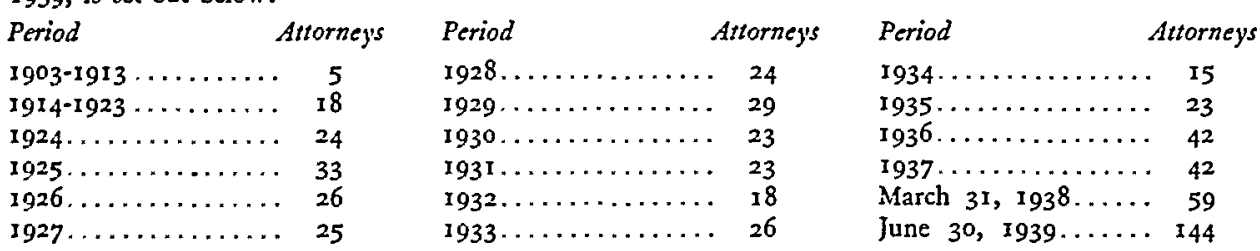


employed at any one time as by the number of lawyers available when the complaint has reached the stage for general investigation. Since the whole staff is usually employed in pending matters, a new general investigation has to be deferred either until a pending case is concluded or until a major investigation is terminated.

Limitation of personnel makes availability of information an important factor in the selection of matters for major investigation. Therefore, it is not surprising that many major investigations and litigations grow out of previous investigations by the Federal Trade Commission.

It sometimes happens that the preliminary investigation yields sufficient information to support immediate legal action. This most frequently occurs when the complainant's interest in enforcement is so vital that he has conducted an investigation to secure facts supporting his complaint. Familiarity with the industry and access to confidentíal, sources of information make independent investigation of this type particularly fruitful.

Since a rigid process of selection must precede a major investigation, the final decision must necessarily be one of administrative judgment. The economic benefits that may reasonably be anticipated through eliminating combinations in restraint of trade are one of the important consequences. With the economic considerations must be balanced such legal ones as the effect which any case that may result from the investigation will have upon antitrust law enforcement. If practices have grown inveterate and have been boldly maintained so that their existence is a matter of common knowledge, then, if they are unlawful, enforcement has a powerful deterrent effect. Where there is doubt about the legality of a widespread practice, action may be necessary to secure an authoritative determination of its validity. A case small in its immediate economic effect may through its importance as a precedent attain major significance.

A decision to undertake a major investigation is only reached after careful consideration of all of these factors. The lawyer who has supervised the preliminary investigation makes a report of that inquiry and couples with it his recommendation whether a major investigation is necessary. Thereafter, the matter is considered by a committee composed of the assistant to the Assistant Attorney General in charge of the Antitrust Division and the heads of the various sections of the Antitrust Division who consider the memorandum, discuss the situation with the lawyer who has handled the preliminary investigation and determine whether any additional information, legal or economic, should be secured before a decision as to the major investigation can be made. After mature consideration, this committee makes a recommendation to the Assistant Attorney General in charge of the Antitrust Division. He then discusses the matter with the committee and reaches a final decision as to further action.

When it is determined that a major investigation is to be undertaken, a unit is organized to handle the matter. Although the size of the unit varies with the importance of the investigation and the number of men available, an attempt is 